\title{
Survey of the fatty acid composition of Canadian beef: Backfat and longissimus lumborum muscle
}

\author{
N. Aldai ${ }^{1}$, M. E. R. Dugan ${ }^{1,3}$, D. C. Rolland ${ }^{1}$, and J. K. G. Kramer ${ }^{2}$ \\ ${ }^{1}$ Lacombe Research Centre, Agriculture and Agri-Food Canada, Lacombe, Alberta, Canada T4L 1W1; and ${ }^{2}$ Guelph \\ Food Research Centre, Agriculture and Agri-Food Canada, Guelph, Ontario, Canada N1G 5C9. \\ Received 4 December 2008, accepted 29 April 2009.
}

\begin{abstract}
Aldai, N., Dugan, M. E. R., Rolland, D. C. and Kramer, J. K. G. 2009. Survey of the fatty acid composition of Canadian beef: Backfat and longissimus lumborum muscle. Can. J. Anim. Sci. 89: 315-329. A survey of Canadian retail beef was undertaken with emphasis on the trans fatty acid (TFA) and conjugated linoleic acid (CLA) isomers, and compared with current health recommendations. Thirty striploin steaks were collected in the winter and summer from major grocery stores in Calgary (Alberta, Canada). Steak fatty acid compositions (backfat and longissimus lumborum muscle analysed separately) showed minor seasonal differences with lower total saturates $(P<0.05)$ and higher total monounsaturates $(P<$ $0.01)$ in winter, but no differences in total polyunsaturated fatty acids. The ratio of n-6 and n-3 polyunsaturated fatty acid in longissimus lumborum averaged 5.8. The average TFA content in longissimus lumborum was $0.128 \mathrm{~g}^{100 \mathrm{~g}^{-1}} \mathrm{serving}$ size, and 10t-18:1 was found to be the predominant isomer (32\% of total trans), while vaccenic acid was second most abundant (15\% of total trans). The CLA content in longissimus lumborum was similar to that of backfat, ranging from 0.43 to $0.60 \%$ of total fatty acids and rumenic acid represented $60 \%$ of total isomers. Overall, there is still room for improvement in the saturated, mono- and polyunsaturated fatty acid composition of Canadian beef to meet general dietary guidelines for human consumption and additional targets should include reducing 10t-18:1 while increasing both rumenic and vaccenic acids.
\end{abstract}

Key words: Beef, conjugated linoleic acid, survey, trans fatty acids, vaccenic acid

\begin{abstract}
Aldai, N., Dugan, M. E. R., Rolland, D. C. et Kramer, J. K. G. 2009. Les acides gras dans le bæuf canadien : gras dorsal et longissimus lumborum. Can. J. Anim. Sci. 89: 315-329. Les auteurs ont entrepris une enquête sur le bæuf canadien vendu au détail en insistant sur les isomères des acides gras trans (AGT) et de l'acide linoléique conjugué (ALC), puis ils ont comparé leurs résultats aux recommandations actuelles relatives à la santé. À cette fin, ils ont recueilli trente beefsteaks d'entrecôte dans les principales épiceries de Calgary (Alberta, Canada) en hiver et en été. La composition en acides gras de la viande (analyse distincte du gras dorsal et du longissimus lumborum) révèle de faibles variations saisonnières, avec une plus basse concentration totale d'acides gras saturés $(P<0,05)$ et une concentration plus élevée d'acides gras monoinsaturés $(P<0,01)$ en hiver, sans écart au niveau de la concentration totale d'acides gras polyinsaturés. Le ratio entre les AGP n-6 et n-3 dans le longissimus lumborum s'établissait en moyenne à 5,8. Le longissimus lumborum was renferme en moyenne $0,128 \mathrm{~g}$ d'AGT par portion de $100 \mathrm{~g}$ et l'isomère prédominant est le $10 t-18: 1$ (32\% de la concentration totale d'AGT), l'acide vaccénique arrivant au deuxième rang (15\% de la concentration totale d'AGT). Le lngissimus lumborum contient autant d'ALC que le gras dorsal, soit de 0,43 à $0,60 \%$, l'acide ruménique constituant $60 \%$ de l'ensemble des isomères. Globalement, en ce qui concerne la composition en acides gras mono et polyinsaturés, le bæuf canadien a encore du chemin à faire avant de respecter les directives générales eu égard à l'alimentation humaine, et on devrait envisager de réduire le ratio de 10t-18:1 ainsi qu'accroître la concentration des acides vaccénique et ruménique.
\end{abstract}

Mots clés: Bœuf, ALC, acides gras trans, acide vaccénique

The fat content and fatty acid composition of beef are outstanding aspects of quality that consumers consider important as they focus on the healthiness and nutritional value of all commercial foods (Scollan et al. 2006). Current recommendations for human health in many countries suggest reducing the level of total dietary fat $(<15-30 \%)$, saturated fatty acids (SFA) $(<10 \%$, particularly limiting the intake of $14: 0$ and 16:0), and $n-6$ polyunsaturated fatty acids (PUFA) $(<5-8 \%)$, while increasing the intake of $n-3$ PUFAs $(>1-2 \%)$ of total

${ }^{3}$ To whom correspondence should be addressed (e-mail: mike.dugan@agr.gc.ca). energy intake to maintain a n-6/n-3 ratio of $<5: 1$, and a P:S ratio above 0.4 (World Health Organization 2003). With mounting evidence that trans fatty acids (TFA) are linked to increased risk for cardiovascular disease

\begin{abstract}
Abbreviations: $\mathrm{Ag}^{+}$-HPLC, silver-ion high performance liquid chromatography; BCFA, branched-chain fatty acid; CLA, conjugated linoleic acid; DMA, dimethylacetal; GC, gas chromatography; MUFA, monounsaturated fatty acid; OCFA, odd-chain fatty acid; PUFA, polyunsaturated fatty acid; SFA, saturated fatty acid; TFA, trans fatty acid
\end{abstract}


(Mensink et al. 2003), many countries have introduced mandatory labelling of the total TFA content in foods, which includes TFA with isolated double bonds, but excludes conjugated linoleic acid (CLA) (Ratnayake and Zehaluk 2005). Consequently, some healthy trans fats may be included in the total TFA label, such as vaccenic acid (11t-18:1), while all CLA isomers, healthy (i.e., rumenic acid $9 c, 11 t$-18:2) or otherwise, are excluded. This has specific implications with regard to dairy and meat products from ruminants. In the Danish regulations, ruminant products are excluded (Ratnayake and Zehaluk 2005), on the assumption that these TFA are of no concern since they are thought to be mainly vaccenic and rumenic acids, both of which have been shown to have beneficial health effects (Belury 2002; Ip et al. 2003). However, several reports are now showing that the TFA and CLA pattern in ruminant products can be altered depending on the diet fed and can result in increased levels of total TFA, specifically 10t-18:1 (Purchas et al. 2005; Roy et al. 2006; Cruz-Hernandez et al. 2007). In addition, the trans-18:1 isomers, notably $10 t-18: 1$, can be found at increased levels in intensively finished beef (Dugan et al. 2007) and this TFA isomer has been shown to be atherogenic in humans (Hodgson et al. 1996) and in animal models (Bauchart et al. 2007; Roy et al. 2007).

Surveys of the fatty acid composition of Canadian beef products are limited (Ma et al. 1999; Beef Information Centre 2008; Health Canada 2008) and the detailed fatty acid composition (including trans and CLA isomers) of Canadian beef at the retail level is currently not available. Therefore, the present survey was undertaken to elucidate the fatty acid composition of Canadian beef available at the retail level and to see how it compares with current health recommendations. In Canada, $65 \%$ of beef is finished in the province of Alberta (CanFax Research Services 2008), and for the present survey, sampling was limited to major retail outlets in Calgary, Alberta, Canada.

\section{MATERIALS AND METHODS}

\section{Sample Collection and Preparation}

Striploin steaks from Canada A/AA Grade (youthful) beef were collected on one day in February (winter, $n=$ 30 ) and one day in July (summer, $n=30$ ) 2007, from the four major grocery store chains in Calgary (Alberta, Canada) with one steak collected per store per time period. Beef was collected in summer as animals slaughtered during this time period would likely have been placed in the feedlot directly after weaning, while animals slaughtered in early winter would likely be pastured as yearlings prior to entering the feedlot in the fall (Basarab et al. 2005). Precise details of production systems for beef used in the present study are unknown. After collection, samples were stored on ice in insulated picnic coolers and transported to the laboratory in Lacombe (Alberta, Canada).
From the striploin steak $5 \mathrm{~g}$ of backfat was sampled from the mid-point of the steak and stored separately at $-80^{\circ} \mathrm{C}$. The steak was then trimmed of remaining subcutaneous and seam fat and the epimysium (outer layer of connective tissue), and the longissimus lumborum muscle was comminuted using a Robot Coupe Blixer BX3 (Robot Coupe USA Inc., Ridgeland, MS). A subsample of $15-20 \mathrm{~g}$ was stored at $-80^{\circ} \mathrm{C}$ for subsequent fatty acid determinations.

\section{Fatty Acid Analysis}

Backfat samples $(50 \mathrm{mg})$ were freeze-dried and directly methylated with sodium methoxide and lipids were extracted from $1 \mathrm{~g}$ of freeze-dried muscle sample using a mixture of chloroform-methanol $(1: 1, \mathrm{vol} / \mathrm{vol})$ (Kramer et al. 1998). Each sample was homogenized in $5 \mathrm{~mL}$ of methanol, and then $5 \mathrm{~mL}$ of chloroform was added and homogenized again. The mixture was filtered through a sintered glass filter funnel. The homogenizer (Cyclone IQ2, VirTis Company, Gardiner, NY) was rinsed with another $10 \mathrm{~mL}$ of chloroform-methanol (1:1, $\mathrm{vol} / \mathrm{vol}$ ) and filtered through the same glass funnel and pooled with the first extract. The final volume was adjusted to contain exactly $20 \mathrm{~mL}$ chloroform-methanol $(1: 1, \mathrm{vol} / \mathrm{vol})$ and $9 \mathrm{~mL} 0.88 \%$ potassium chloride solution and 1 drop of $6 \mathrm{~N}$ hydrochloric acid were added. The solution was mixed and centrifuged $(600 \times g)$ to separate phases. The bottom organic layer (chloroform) was removed and another $10 \mathrm{~mL}$ of chloroform were added to rinse the aqueous phase again (methanolwater), mixed and centrifuged. The bottom organic layer was collected and pooled with the first one. The chloroform was evaporated using a rotary evaporator (Büchi, Model R-114, Labortechnik, Switzerland) and total lipids were dissolved in $15 \mathrm{~mL}$ of chloroform. Lipid aliquots $(10 \mathrm{mg})$ from each steak were methylated separately using acidic (methanolic $\mathrm{HCl}$ ) and basic (sodium methoxide) reagents (Kramer et al. 2008). The fatty acid methyl esters were analyzed using the gas chromatography (GC) and $\mathrm{Ag}^{+}$-HPLC equipment and methods outlined by Cruz-Hernandez et al. (2004), and the trans-18:1 isomers were analyzed using two complementary GC temperature programs (Dugan et al. 2007; Kramer et al. 2008).

\section{Statistical Analysis}

Fatty acid composition data for backfat (\%) and meat

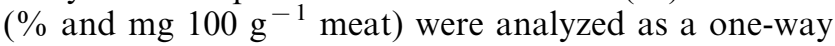
ANOVA with collection period as the main effect using PROC MIXED (SAS Institute, Inc. 2001). Polynomial regressions incorporating linear and quadratic coefficients were also conducted using the GLM procedure of SAS to evaluate the relationship between selected biohydrogenation products of PUFA. For instances where the quadratic effects were not significant $(P>0.05)$ data were reprocessed with only the linear effect. 


\section{RESULTS AND DISCUSSION}

\section{Backfat Composition}

Backfat SFA composition for both collection periods is summarized in Table 1. Samples collected in summer had significantly more SFA than samples collected in winter (44.2 and $41.8 \%$, respectively; $P=0.005)$ and this was mostly attributed to the higher percentage of 16:0 in summer samples $(P<0.001)$, which is the major SFA in beef (Rule et al. 1995). Percentages of 12:0 and 14:0 were also significantly higher in samples from summer than winter $(P<0.001)$, while the odd-chain fatty acids (OCFA) 17:0 and 19:0 were significantly higher in winter samples. No differences in total branched-chain fatty acids (BCFA) were observed; however, 15:0anteiso was slightly lower in winter $(P=0.027)$ while 17:0anteiso $(P=0.003)$ and 18:0iso $(P=0.031)$ were higher. As found in previous studies (Dugan et al. 2007) 17:0anteiso and 17:0iso were the most abundant BCFAs. Differences in SFA likely relate to climatic differences. Colder temperatures in winter increase $\Delta^{9}$-desaturase activity converting SFA to monounsaturated fatty acids (MUFA), which is required to maintain fat in a fluid state (Tume 2004). Colder temperatures in winter also increase rates of digesta passage from the rumen (Kennedy et al. 1977), which may limit time available for biohydrogenation of PUFA to SFA. In addition, increased rates of passage would alter rumen volatile fatty acid production in favour of proprionate instead of acetate (Kennedy et al. 1977), with acetate being the major precursor for even-chain fatty acid synthesis, while proprionate is a precursor for OCFA synthesis.

Backfat MUFA composition for both collection periods is summarized in Table 2. In contrast to SFA,

\begin{tabular}{|c|c|c|c|c|}
\hline Fatty acid (\%) & Winter & Summer & SEM $^{\mathbf{z}}$ & $\mathrm{P}$ \\
\hline $12: 0$ & 0.05 & 0.08 & 0.002 & $<0.001$ \\
\hline 14:0 & 2.69 & 3.50 & 0.065 & $<0.001$ \\
\hline 15:0iso & 0.11 & 0.12 & 0.005 & 0.395 \\
\hline 15:0anteiso & 0.16 & 0.19 & 0.007 & 0.027 \\
\hline $15: 0$ & 0.58 & 0.63 & 0.019 & 0.253 \\
\hline 16:0iso & 0.16 & 0.21 & 0.018 & 0.185 \\
\hline $16: 0$ & 23.0 & 25.8 & 0.229 & $<0.001$ \\
\hline 17:0iso & 0.36 & 0.36 & 0.009 & 0.664 \\
\hline 17:0anteiso & 0.87 & 0.73 & 0.022 & 0.003 \\
\hline $17: 0$ & 1.61 & 1.37 & 0.056 & 0.041 \\
\hline 18:0iso & 0.16 & 0.14 & 0.004 & 0.031 \\
\hline $18: 0$ & 11.9 & 11.0 & 0.337 & 0.200 \\
\hline 19:0 & 0.10 & 0.05 & 0.002 & $<0.001$ \\
\hline $20: 0$ & 0.09 & 0.08 & 0.004 & 0.068 \\
\hline $17: 0-$ cyclo $^{\mathbf{y}}$ & 0.05 & 0.05 & 0.003 & 0.964 \\
\hline$\Sigma \mathrm{BCFA}^{\mathrm{z}}$ & 1.82 & 1.75 & 0.046 & 0.430 \\
\hline$\Sigma \mathrm{SFA}^{\mathbf{z}}$ & 41.8 & 44.2 & 0.420 & 0.005 \\
\hline
\end{tabular}

${ }^{\mathrm{z}} \mathrm{SEM}$, standard error of the mean; BCFA, branched fatty acids (includes iso and anteiso); SFA, saturated fatty acids.

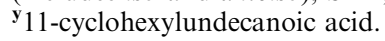

the total monounsaturated percentage was significantly higher in winter than in summer (54.8 and 52.5\%, respectively; $P=0.006$ ) attributed mainly to the cismonounsaturates $(51.2$ and $48.6 \%$, respectively; $P=$ $0.008)$. These differences are likely related to the aforementioned climatic differences noted for SFA. In general, there were no significant differences in the content of the trans-MUFA between collections, except for two minor isomers (15t- and 16t-18:1). Across collection periods, the total trans-18:1 averaged $3.77 \pm$ $0.16 \%$ and ranged from 1.38 to $7.23 \%$. This high variability in total trans-18:1 content may be due to several factors including individual animal variation combined with differences in production systems and management practices (i.e., age/live weight at slaughter, genetics, feeding strategies, usage of antibiotics) (Dannenberger et al. 2004; Eifert et al. 2006; Aldai et al. 2007; Dugan et al. 2008). The major isomer found was 10t-18:1 $(1.64 \pm 0.12 \%$, ranged from 0.15 to $4.55 \%)$, which was twofold greater than the second most abundant isomer $11 t-18: 1(0.73 \pm 0.04 \%$, ranged from 0.20 to $1.55 \%)$. These results were intermediate to results obtained with

\begin{tabular}{|c|c|c|c|c|}
\hline Fatty acid (\%) & Winter & Summer & SEM $^{\mathbf{z}}$ & $P$ \\
\hline $9 c-14: 1$ & 1.01 & 1.27 & 0.067 & 0.059 \\
\hline $9 c-15: 1$ & 0.03 & 0.03 & 0.002 & 0.827 \\
\hline $7 c-16: 1$ & 0.05 & 0.08 & 0.004 & 0.002 \\
\hline $9 c-16: 1$ & 4.05 & 4.92 & 0.193 & 0.029 \\
\hline $11 c-16: 1$ & 0.27 & 0.27 & 0.016 & 0.888 \\
\hline $13 c-16: 1$ & 0.09 & 0.11 & 0.006 & 0.132 \\
\hline $9 c-17: 1$ & 1.52 & 1.29 & 0.044 & 0.012 \\
\hline $9 c-18: 1^{\mathbf{y}}$ & 40.8 & 37.5 & 0.383 & $<0.001$ \\
\hline $11 c-18: 1$ & 1.92 & 1.79 & 0.041 & 0.132 \\
\hline $12 c-18: 1$ & 0.15 & 0.20 & 0.010 & 0.012 \\
\hline $13 c-18: 1$ & 0.59 & 0.50 & 0.022 & 0.045 \\
\hline $14 c-18: 1$ & 0.03 & 0.04 & 0.001 & $<0.001$ \\
\hline $15 c-18: 1$ & 0.18 & 0.21 & 0.010 & 0.174 \\
\hline $9 c-20: 1$ & 0.14 & 0.11 & 0.004 & $<0.001$ \\
\hline $11 c-20: 1$ & 0.34 & 0.25 & 0.011 & $<0.001$ \\
\hline$\Sigma$ cis MUFA & 51.2 & 48.6 & 0.468 & 0.008 \\
\hline $11 t / 12 t-16: 1$ & 0.02 & 0.02 & 0.001 & 0.082 \\
\hline $6 t / 7 t / 8 t-18: 1$ & 0.22 & 0.21 & 0.013 & 0.824 \\
\hline $9 t-18: 1$ & 0.27 & 0.28 & 0.012 & 0.832 \\
\hline $10 t-18: 1$ & 1.62 & 1.65 & 0.117 & 0.906 \\
\hline $11 t-18: 1$ & 0.71 & 0.75 & 0.040 & 0.675 \\
\hline $12 t-18: 1$ & 0.15 & 0.17 & 0.008 & 0.211 \\
\hline $13 t / 14 t-18: 1^{\mathbf{x}}$ & 0.39 & 0.36 & 0.020 & 0.392 \\
\hline $15 t-18: 1$ & 0.13 & 0.41 & 0.017 & $<0.001$ \\
\hline $16 t-18: 1$ & 0.12 & 0.09 & 0.006 & 0.045 \\
\hline$\Sigma$ trans MUFA & 3.63 & 3.95 & 0.161 & 0.332 \\
\hline$\Sigma 10 t-\& 11 t-18: 1$ & 2.34 & 2.40 & 0.118 & 0.796 \\
\hline $11 t-/ 10 t-18: 1$ & 0.60 & 0.70 & 0.075 & 0.508 \\
\hline$\Sigma$ MUFA & 54.8 & 52.5 & 0.395 & 0.006 \\
\hline
\end{tabular}

${ }^{\mathrm{z}} \mathrm{SEM}$, standard error of the mean; MUFA, monounsaturated fatty acids.

${ }^{\mathbf{y}}$ Coelution with $10 c-18: 1$.

${ }^{\mathrm{x}}$ Coelution with $6 c / 7 c / 8 c-18: 1$. 
animals finished on a $73 \%$ barley grain diet $(2.13 \%$ $10 t-18: 1$ and $0.77 \% 11 t-18: 1$; Dugan et al. 2007) or a $81 \%$ barley grain diet $(0.82 \% 10 t-18: 1$ and $0.54 \% 11 t$ 18:1; Aldai et al. 2008a). The aforementioned two trans$18: 1$ isomers represented $63 \%$ of the total trans-18:1 content and the higher levels of total trans-18:1 were associated with higher levels of $10 t-18: 1$, and not vaccenic acid (11t-18:1) as demonstrated in Fig. 1.

Backfat PUFA composition and calculated ratios $(\mathrm{P} /$ $\mathrm{S}, \mathrm{n}-6 / \mathrm{n}-3)$ of both collection periods are presented in Table 3. A higher percentage of n-3 PUFA in samples collected in winter was anticipated given that these animals likely gained more weight on pasture relative to animals going directly to the feedlot after weaning (Realini et al. 2004; Dugan et al. 2007). However, this was not the case as the effect of pasture on beef fatty acid composition can be rapidly lost with a short period of concentrate finishing before slaughter (Aldai et al. 2008b). In general, no significant differences were found for the methylene interrupted n-6 and n-3 PUFA (except for 20:3n-6; $P<0.001$ ), calculated ratios and CLA. Across collection periods, total CLA averaged $0.57 \pm$ $0.02 \%$ and ranged from 0.27 to $1.22 \%$. The major CLA isomer was $9 c, 11 t-18: 2(0.35 \pm 0.02 \%$, ranged from 0.08 to $0.93 \%)$ followed by $7 t, 9 c-18: 2(0.08 \pm 0.001 \%$, ranged from 0.01 to $0.15 \%$ ). Results for the total and individual CLA isomers are similar to values previously reported for barley-finished beef (Dugan et al. 2007; Aldai et al. 2008a). In general, the content (\%) of total CLA was associated with higher levels of the major isomer (i.e., $9 c, 11 t-18: 2)$, but not the second most abundant isomer (i.e., $7 t, 9 c-18: 2$ ) as shown in Fig. 2.

The $\mathrm{P} / \mathrm{S}$ and $\mathrm{n}-6 / \mathrm{n}-3$ ratios from the backfat tissue of these striploin steaks were comparable with values obtained in backfat tissue from concentrate-finished (73-81\% barley) beef cattle (Dugan et al. 2007; Aldai et al. 2008a).

\section{Muscle Composition}

Compared with backfat (Tables 1, 2 and 3), muscle contained more identifiable fatty acids (Tables 4,5 and

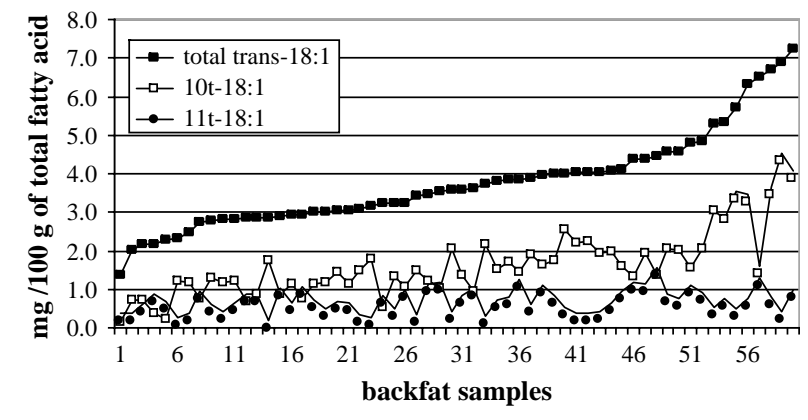

Fig. 1. Abundance of $10 t-18: 1$ and $11 t-18: 1$ as percent of total lipids after sorting all backfat samples in increasing order of total trans-18:1 $(n=60)$.

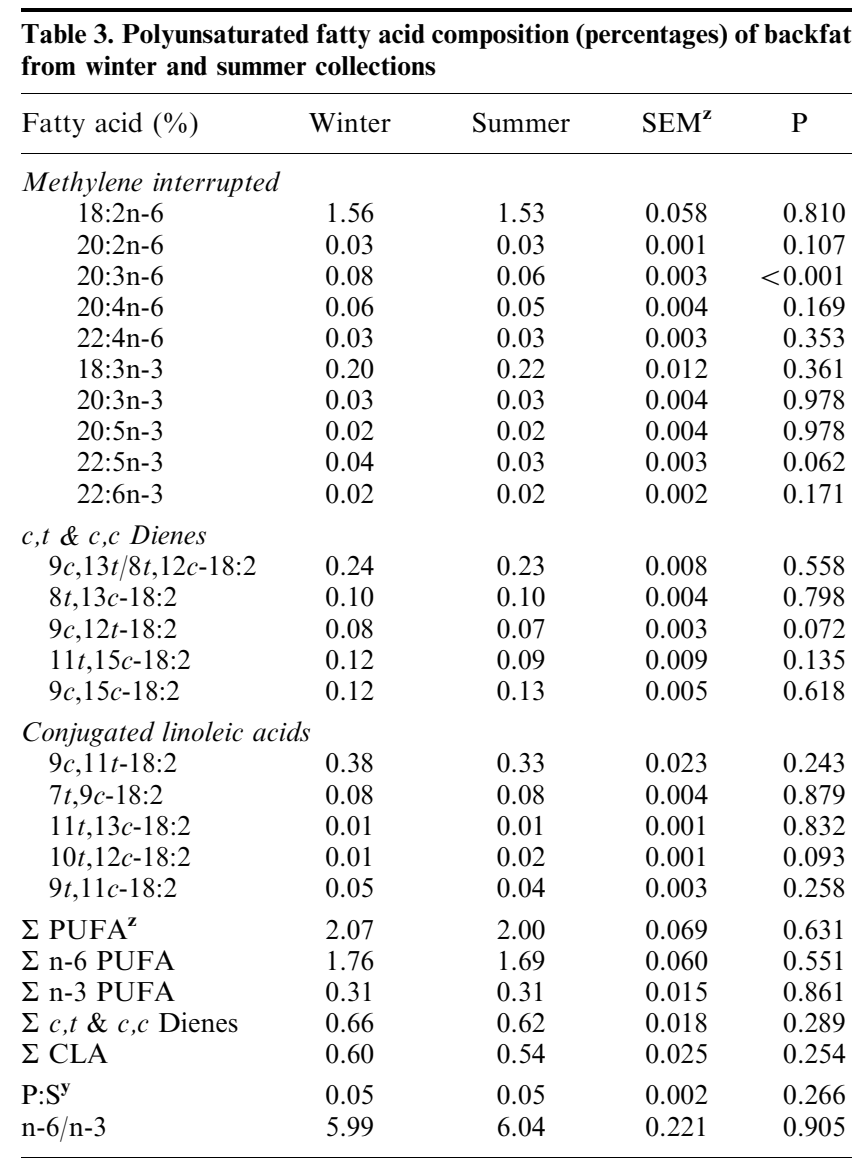

${ }^{\mathrm{z}} \mathrm{SEM}$, standard error of the mean; PUFA, polyunsaturated fatty acids CLA, conjugated linoleic acids.

${ }^{\mathbf{y}} \mathrm{P}: \mathrm{S}$, polyunsaturated to saturated fatty acid ratio.

6). The additional methyl esters quantified in muscle included those of long-chain SFA (21:0, 22:0, 24:0), cisand trans-MUFA $(10 c-16: 1,12 c-16: 1,5 c-17: 1,7 c-17: 1$, 11c-17:1, 5t-18:1), methylene interrupted PUFA (18:3n6 ), some additional dienes $(9 t, 12 t-18: 2,9 t, 12 c-18: 2)$ and dimethylacetals derived from plasmalogens (DMA;

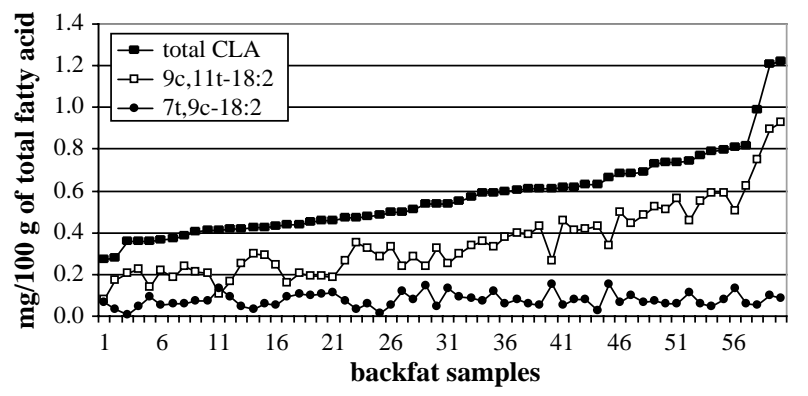

Fig. 2. Relative abundance of $9 c, 11 t-18: 2$ and $7 t, 9 c-18: 2$ as percent of total lipids after sorting all backfat samples in increasing order of total CLA $(n=60)$. 


\begin{tabular}{|c|c|c|c|c|c|c|c|c|}
\hline & Winter & Summer & $\mathrm{SEM}^{\mathbf{z}}$ & $P$ & Winter & Summer & SEM & $P$ \\
\hline Fatty acid & 4,304 & 3,636 & 232.9 & 0.157 & \multirow{2}{*}{\multicolumn{4}{|c|}{$(\%$ of total FAME) }} \\
\hline$\Sigma$ FAME & \multicolumn{4}{|c|}{ (mg $100 \mathrm{~g}^{-1}$ of meat) } & & & & \\
\hline $12: 0$ & 1.28 & 1.31 & 0.105 & 0.884 & 0.03 & 0.03 & 0.001 & 0.055 \\
\hline $14: 0$ & 97.2 & 89.7 & 6.292 & 0.558 & 2.22 & 2.40 & 0.050 & 0.081 \\
\hline 15:0iso & 3.43 & 3.38 & 0.267 & 0.932 & 0.08 & 0.09 & 0.004 & 0.214 \\
\hline 15:0anteiso & 4.60 & 4.80 & 0.289 & 0.725 & 0.11 & 0.13 & 0.005 & 0.024 \\
\hline $15: 0$ & 19.0 & 16.9 & 1.163 & 0.365 & 0.44 & 0.46 & 0.013 & 0.560 \\
\hline 16:0DMA & 36.1 & 34.7 & 0.965 & 0.480 & 0.98 & 1.07 & 0.055 & 0.386 \\
\hline 16:0iso & 5.49 & 5.38 & 0.360 & 0.875 & 0.13 & 0.14 & 0.005 & 0.214 \\
\hline 16:1DMA & 1.61 & 1.45 & 0.047 & 0.093 & 0.04 & 0.04 & 0.002 & 0.515 \\
\hline $16: 0$ & 1036 & 890 & 57.38 & 0.210 & 24.0 & 24.3 & 0.180 & 0.405 \\
\hline 17:0iso & 13.2 & 12.3 & 0.701 & 0.511 & 0.31 & 0.34 & 0.007 & 0.033 \\
\hline 17:0anteiso & 21.9 & 18.9 & 1.344 & 0.272 & 0.50 & 0.51 & 0.011 & 0.686 \\
\hline $17: 0$ & 57.5 & 48.3 & 3.593 & 0.206 & 1.33 & 1.31 & 0.039 & 0.758 \\
\hline 18:0DMA & 19.6 & 18.9 & 0.499 & 0.513 & 0.54 & 0.58 & 0.028 & 0.428 \\
\hline 18:0iso & 4.82 & 4.42 & 0.327 & 0.537 & 0.11 & 0.12 & 0.003 & 0.511 \\
\hline 18:1DMA & 1.69 & 1.83 & 0.118 & 0.551 & 0.04 & 0.05 & 0.003 & 0.051 \\
\hline $18: 0$ & 502 & 456 & 29.18 & 0.427 & 11.8 & 12.5 & 0.206 & 0.062 \\
\hline 19:0 & 3.30 & 2.84 & 0.268 & 0.390 & 0.08 & 0.08 & 0.004 & 0.762 \\
\hline $20: 0$ & 3.42 & 2.97 & 0.223 & 0.325 & 0.08 & 0.08 & 0.003 & 0.404 \\
\hline $21: 0$ & 0.89 & 0.85 & 0.046 & 0.622 & 0.02 & 0.02 & 0.001 & 0.256 \\
\hline $22: 0$ & 2.30 & 2.28 & 0.103 & 0.905 & 0.06 & 0.07 & 0.002 & 0.120 \\
\hline $24: 0$ & 1.32 & 0.94 & 0.075 & 0.014 & 0.03 & 0.03 & 0.002 & 0.164 \\
\hline $17: 0-$ cyclo $^{\mathbf{y}}$ & 3.28 & 3.47 & 0.209 & 0.657 & 0.08 & 0.10 & 0.003 & 0.060 \\
\hline$\Sigma \mathrm{BCFA}^{\mathbf{z}}$ & 53.4 & 49.2 & 3.176 & 0.504 & 1.25 & 1.34 & 0.029 & 0.148 \\
\hline$\Sigma \mathrm{DMA}^{\mathbf{z}}$ & 58.9 & 56.9 & 1.411 & 0.471 & 1.60 & 1.76 & 0.083 & 0.359 \\
\hline$\Sigma \mathrm{SFA}^{\mathrm{z}}$ & 1,778 & 1,561 & 99.26 & 0.280 & 41.3 & 42.7 & 0.296 & 0.026 \\
\hline
\end{tabular}

${ }^{\mathbf{z}}$ SEM, standard error of the mean; BCFA, branched fatty acids (includes iso and anteiso); DMA, dimethylacetals; SFA, saturated fatty acids.

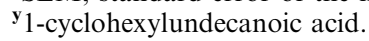

16:0DMA, 16:1DMA, 18:0DMA, 18:1DMA). The aforementioned methyl ester derivatives were either not detected or below quantification limits in the backfat samples. Considering the lipid complexity of meat samples and the chemical nature of all lipid structures, accurate and reliable methods were required for detailed fatty acid analyses (Cruz-Hernandez et al. 2006; Santercole et al. 2007; Kraft et al. 2008). For meat samples, this included base-catalyzed methylation to analyze CLA isomers, which are acid sensitive (Kramer et al. 1997), and acid-catalyzed methylation required for the analysis of plasmalogens and sphingolipids, which contribute up to $15 \%$ of the total meat polar lipids (Horrocks 1972).

The total intramuscular fatty acid content $\left(\mathrm{mg} 100 \mathrm{~g}^{-1}\right.$ of meat) and SFA composition (mg $100 \mathrm{~g}^{-1}$ meat and percentages) of both collection periods are summarized in Table 4. Total intramuscular fatty acids were not statistically different between collection periods (average

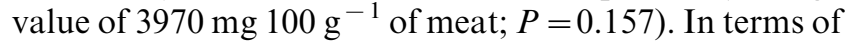
absolute contents, there were no differences between collections for SFA (except for 24:0; $P=0.014$ ), BCFA and DMA. Plasmalogen synthesis is not fully understood, and it is believed that several factors influence this process (Snyder et al. 1985). Both breed (Kraft et al. 2008) and diet (Dannenberger et al. 2006) differences have been reported to affect the total fatty aldehyde content in beef animals. Expressed as percentages, however, few significant differences were found. The percentage of 15:0anteiso and 17:0iso were higher $(P<0.05)$ in summer although no difference was found for the total BCFA. Total SFA was significantly higher in summer compared with winter (42.7 and $41.3 \%$, respectively; $P=0.026$ ), and this was mostly attributed to trends for higher percentages of 14:0 $(P=0.081)$ and 18:0 (second most abundant SFA; $P=0.062$ ), but compared with backfat differences in SFA were rather limited. As postulated for backfat, the reason for a lower SFA content in samples collected in winter could be related to the ambient temperature (Duncan and Garton 1967). However, such differences resulting from direct temperature effects are more likely to occur in backfat (subcutaneous fat) because of the temperature homeostasis of deeper tissues. Intracellular fatty acid composition changes to maintain constant lipid fluidity and allow for normal metabolic function. This regulation appears to be primarily achieved by $\Delta^{9}$-desaturase activity (Kouba et al. 1999), with activity being greater in cooler tissues. 


\begin{tabular}{|c|c|c|c|c|c|c|c|c|}
\hline & Winter & Summer & $\mathrm{SEM}^{\mathbf{z}}$ & $P$ & Winter & Summer & SEM & $P$ \\
\hline Fatty acid & \multicolumn{4}{|c|}{ (mg $100 \mathrm{~g}^{-1}$ of meat) } & \multicolumn{4}{|c|}{ (\% of total FAME) } \\
\hline $9 c-14: 1$ & 27.3 & 22.1 & 2.010 & 0.205 & 0.61 & 0.58 & 0.026 & 0.529 \\
\hline $9 c-15: 1$ & 3.08 & 2.56 & 0.119 & 0.032 & 0.08 & 0.08 & 0.003 & 0.699 \\
\hline $7 c-16: 1$ & 6.40 & 5.93 & 0.354 & 0.510 & 0.15 & 0.16 & 0.002 & 0.011 \\
\hline $9 c-16: 1$ & 158 & 132 & 9.311 & 0.167 & 3.68 & 3.57 & 0.089 & 0.521 \\
\hline $10 c-16: 1$ & 1.67 & 1.43 & 0.105 & 0.245 & 0.04 & 0.04 & 0.001 & 0.858 \\
\hline $11 c-16: 1$ & 8.73 & 6.79 & 0.575 & 0.097 & 0.20 & 0.18 & 0.007 & 0.251 \\
\hline $12 c-16: 1$ & 1.05 & 1.00 & 0.068 & 0.754 & 0.03 & 0.03 & 0.001 & 0.139 \\
\hline $13 c-16: 1$ & 3.64 & 2.98 & 0.192 & 0.092 & 0.09 & 0.08 & 0.003 & 0.482 \\
\hline $5 c-17: 1$ & 1.37 & 1.32 & 0.075 & 0.741 & 0.03 & 0.04 & 0.001 & 0.209 \\
\hline $7 c-17: 1$ & 1.31 & 1.30 & 0.075 & 0.945 & 0.03 & 0.04 & 0.001 & 0.097 \\
\hline $9 c-17: 1$ & 58.5 & 45.5 & 3.219 & 0.048 & 1.37 & 1.26 & 0.038 & 0.128 \\
\hline $11 c-17: 1$ & 1.49 & 1.76 & 0.103 & 0.212 & 0.04 & 0.05 & 0.002 & $<0.001$ \\
\hline $9 c-18: 1^{\mathbf{y}}$ & 1735 & 1362 & 100.3 & 0.069 & 39.6 & 37.3 & 0.315 & $<0.001$ \\
\hline $11 c-18: 1$ & 80.3 & 66.6 & 4.123 & 0.101 & 1.89 & 1.84 & 0.025 & 0.259 \\
\hline $12 c-18: 1$ & 4.70 & 4.59 & 0.302 & 0.848 & 0.11 & 0.13 & 0.007 & 0.190 \\
\hline $13 c-18: 1$ & 22.1 & 15.8 & 1.430 & 0.032 & 0.49 & 0.42 & 0.014 & 0.013 \\
\hline $14 c-18: 1$ & 1.35 & 1.44 & 0.081 & 0.592 & 0.03 & 0.04 & 0.001 & 0.008 \\
\hline $15 c-18: 1$ & 5.88 & 6.15 & 0.400 & 0.739 & 0.14 & 0.17 & 0.007 & 0.028 \\
\hline $9 c-20: 1$ & 3.70 & 3.16 & 0.249 & 0.277 & 0.08 & 0.09 & 0.002 & 0.739 \\
\hline $11 c-20: 1$ & 9.67 & 7.21 & 0.621 & 0.053 & 0.22 & 0.20 & 0.006 & 0.177 \\
\hline$\Sigma$ cis MUFA & 2,135 & 1,692 & 121.0 & 0.072 & 48.9 & 46.2 & 0.359 & $<0.001$ \\
\hline $11 t / 12 t-16: 1$ & 1.82 & 1.56 & 0.103 & 0.212 & 0.04 & 0.04 & 0.001 & 0.951 \\
\hline $5 t-18: 1$ & 1.21 & 0.95 & 0.101 & 0.197 & 0.03 & 0.03 & 0.002 & 0.234 \\
\hline $6 t / 7 t / 8 t-18: 1$ & 5.78 & 6.58 & 0.557 & 0.474 & 0.14 & 0.18 & 0.010 & 0.055 \\
\hline $9 t-18: 1$ & 9.45 & 9.05 & 0.684 & 0.772 & 0.22 & 0.24 & 0.009 & 0.189 \\
\hline $10 t-18: 1$ & 44.7 & 46.1 & 5.815 & 0.908 & 1.01 & 1.21 & 0.089 & 0.247 \\
\hline $11 t-18: 1$ & 19.1 & 17.5 & 1.259 & 0.519 & 0.45 & 0.50 & 0.021 & 0.290 \\
\hline $12 t-18: 1$ & 4.77 & 4.46 & 0.309 & 0.618 & 0.11 & 0.13 & 0.006 & 0.181 \\
\hline $13 t / 14 t-18: 1^{\mathbf{x}}$ & 9.66 & 10.5 & 0.635 & 0.531 & 0.23 & 0.30 & 0.014 & 0.027 \\
\hline $15 t-18: 1$ & 7.82 & 8.27 & 0.458 & 0.627 & 0.18 & 0.24 & 0.007 & $<0.001$ \\
\hline $16 t-18: 1$ & 3.35 & 3.42 & 0.206 & 0.873 & 0.08 & 0.10 & 0.004 & 0.022 \\
\hline$\sum$ trans MUFA & 108 & 108 & 8.739 & 0.972 & 2.49 & 2.96 & 0.118 & 0.051 \\
\hline$\sum 10 t-\& 11 t-18: 1$ & 63.8 & 63.6 & 6.339 & 0.982 & 1.46 & 1.71 & 0.088 & 0.154 \\
\hline $11 t-/ 10 t-18: 1$ & 0.63 & 0.66 & 0.079 & 0.829 & & & & \\
\hline$\Sigma$ MUFA & 2,243 & 1,801 & 127.2 & 0.087 & 51.4 & 49.2 & 0.327 & 0.001 \\
\hline
\end{tabular}

${ }^{\mathbf{z}}$ SEM, standard error of the mean; MUFA, monounsaturated fatty acids.

${ }^{\mathbf{y}}$ Coelution with $10 c-18: 1$.

${ }^{\mathbf{x}}$ Coelution with $6 c / 7 c / 8 c-18: 1$.

Muscle MUFA composition is reported in Table 5. There was a tendency for higher absolute levels of total MUFA in winter compared with summer (2243 and $1801 \mathrm{mg} 100 \mathrm{~g}^{-1}$ of meat, respectively; $P=0.087$ ), which was mostly influenced by the cis-monounsaturates: $9 c-15: 1,9 c-17: 1$, and $13 c-18: 1(P<0.05)$, and $11 c-$ 16:1, 13c-16:1, $9 c-18: 1$ and $11 c-20: 1 \quad(P<0.1)$. These differences are likely related to the aforementioned climatic differences noted for SFA. In addition, the numerically higher fat content of winter samples and the possible higher desaturase activity in fatter animals as found by Siebert et al. (2003) could also help to explain the higher MUFA content of winter samples. For transmonounsaturates, no significant differences were found between collection periods. Across collection periods, the absolute content of total trans-18:1 averaged $108 \pm$
$8.59 \mathrm{mg}$ and ranged from 31.68 to $428.1 \mathrm{mg}^{100 \mathrm{~g}^{-1} \text { of }}$ meat. The major isomer was $10 t-18: 1(45.38 \pm 5.77 \mathrm{mg})$ ranging from 4.22 to $292.8 \mathrm{mg} 100 \mathrm{~g}^{-1}$ of meat, followed by $11 t-18: 1(18.31 \pm 1.25 \mathrm{mg})$ ranging from 4.21 to $49.81 \mathrm{mg} 100 \mathrm{~g}^{-1}$ of meat. High and variable levels of 10t-18:1 likely relate to unstable rumen conditions and altered bacterial populations when feeding highly fermentable concentrate based diets (Bauman and Griinari 2003; Dannenberger et al. 2004; Hristov et al. 2005) and may also in part relate to feeding monensin as a growth promoter (Gustafson and Bowen 1997). Monensin inhibits the growth of gram positive bacteria, including cellulolytic strains of Butyrivibrio fibrisolvens (Chen and Wolin 1979; Russell and Strobel 1989), which are known as the major producers of $11 t$ 18:1 (Kepler et al. 1966). Even without dietary 


\begin{tabular}{|c|c|c|c|c|c|c|c|c|}
\hline \multirow[b]{2}{*}{ Fatty acid } & Winter & Summer & $\mathrm{SEM}^{\mathbf{z}}$ & $P$ & Winter & Summer & SEM & $P$ \\
\hline & \multicolumn{4}{|c|}{ (mg $100 \mathrm{~g}^{-1}$ of meat) } & \multicolumn{4}{|c|}{ ( $\%$ of total FAME) } \\
\hline \multicolumn{9}{|l|}{ Methylene interrrupted } \\
\hline $18: 2 n-6$ & 101.3 & 99.2 & 4.439 & 0.817 & 2.54 & 2.93 & 0.099 & 0.055 \\
\hline $18: 3 n-6$ & 1.24 & 1.12 & 0.065 & 0.375 & 0.03 & 0.03 & 0.002 & 0.871 \\
\hline $20: 2 n-6$ & 2.15 & 1.80 & 0.114 & 0.131 & 0.05 & 0.05 & 0.002 & 0.844 \\
\hline $20: 3 n-6$ & 9.63 & 8.62 & 0.330 & 0.129 & 0.25 & 0.26 & 0.011 & 0.590 \\
\hline $20: 4 n-6$ & 28.0 & 28.4 & 0.899 & 0.810 & 0.77 & 0.87 & 0.045 & 0.286 \\
\hline $22: 4 n-6$ & 4.57 & 3.72 & 0.226 & 0.064 & 0.11 & 0.11 & 0.006 & 0.965 \\
\hline $18: 3 n-3$ & 10.6 & 10.4 & 0.617 & 0.820 & 0.26 & 0.30 & 0.011 & 0.174 \\
\hline $20: 3 n-3$ & 1.42 & 1.43 & 0.119 & 0.943 & 0.03 & 0.04 & 0.003 & 0.254 \\
\hline $20: 5 n-3$ & 3.62 & 4.05 & 0.244 & 0.377 & 0.10 & 0.12 & 0.008 & 0.164 \\
\hline $22: 5 n-3$ & 9.57 & 9.49 & 0.428 & 0.931 & 0.27 & 0.29 & 0.017 & 0.524 \\
\hline $22: 6 n-3$ & 0.96 & 1.24 & 0.068 & 0.040 & 0.03 & 0.04 & 0.002 & 0.027 \\
\hline \multicolumn{9}{|l|}{$t, t ; c, t \& c, c$ Dienes } \\
\hline $9 t, 12 t-18: 2$ & 1.49 & 1.45 & 0.092 & 0.802 & 0.04 & 0.04 & 0.002 & 0.530 \\
\hline $9 c, 13 t / 8 t, 12 c-18: 2$ & 7.28 & 6.72 & 0.385 & 0.472 & 0.17 & 0.19 & 0.005 & 0.080 \\
\hline $8 t, 13 c-18: 2$ & 3.77 & 3.40 & 0.195 & 0.347 & 0.09 & 0.10 & 0.003 & 0.223 \\
\hline $9 c, 12 t-18: 2$ & 2.40 & 2.30 & 0.110 & 0.643 & 0.06 & 0.07 & 0.002 & 0.056 \\
\hline $9 t, 12 c-18: 2$ & 1.35 & 1.16 & 0.087 & 0.279 & 0.03 & 0.03 & 0.002 & 0.444 \\
\hline $11 t, 15 c-18: 2$ & 3.86 & 4.39 & 0.452 & 0.564 & 0.09 & 0.11 & 0.007 & 0.055 \\
\hline $9 c, 15 c-18: 2$ & 7.87 & 5.67 & 0.440 & 0.015 & 0.18 & 0.16 & 0.004 & 0.002 \\
\hline \multicolumn{9}{|l|}{ Conjugated linoleic acids } \\
\hline $9 c, 11 t-18: 2$ & 11.1 & 10.5 & 0.859 & 0.736 & 0.26 & 0.29 & 0.013 & 0.325 \\
\hline $7 t, 9 c-18: 2$ & 2.21 & 2.61 & 0.212 & 0.344 & 0.05 & 0.07 & 0.003 & 0.016 \\
\hline $11 t, 13 c-18: 2$ & 0.34 & 0.30 & 0.039 & 0.591 & 0.01 & 0.01 & 0.001 & 0.923 \\
\hline $10 t, 12 c-18: 2$ & 0.39 & 0.49 & 0.041 & 0.201 & 0.01 & 0.01 & 0.001 & 0.014 \\
\hline $9 t, 11 c-18: 2$ & 1.55 & 1.60 & 0.126 & 0.858 & 0.04 & 0.04 & 0.002 & 0.258 \\
\hline$\Sigma$ PUFA $^{\mathrm{z}}$ & 173 & 169 & 6.053 & 0.768 & 4.44 & 5.03 & 0.168 & 0.085 \\
\hline$\Sigma$ n-6 PUFA & 147 & 143 & 5.430 & 0.716 & 3.75 & 4.25 & 0.148 & 0.098 \\
\hline$\Sigma \mathrm{n}-3$ PUFA & 26.2 & 26.6 & 1.171 & 0.873 & 0.69 & 0.78 & 0.034 & 0.172 \\
\hline$\Sigma \mathrm{t}, \mathrm{t} ; \mathrm{c}, \mathrm{t} \& \mathrm{c}, \mathrm{c}$ Dienes & 28.0 & 25.1 & 1.511 & 0.334 & 0.66 & 0.70 & 0.014 & 0.260 \\
\hline$\Sigma \mathrm{CLA}^{\mathrm{z}}$ & 18.1 & 17.9 & 1.175 & 0.936 & 0.43 & 0.49 & 0.014 & 0.058 \\
\hline$P: S^{y}$ & 0.11 & 0.12 & 0.004 & 0.230 & & & & \\
\hline$n-6 / n-3$ & 5.93 & 5.69 & 0.222 & 0.591 & & & & \\
\hline
\end{tabular}

${ }^{\mathrm{z}} \mathrm{SEM}$, standard error of the mean; PUFA, polyunsaturated fatty acid; CLA, conjugated linoleic acid.

${ }^{\mathrm{P}} \mathrm{P}: \mathrm{S}$, polyunsaturated to saturated fatty acid ratio.

antibiotics, however, a shift towards $10 t-18: 1$ production has been noted (Aldai et al. 2008a) and antibiotics other than monensin (ex., tylosin phosphate) have also been found to influence the trans fatty acid composition

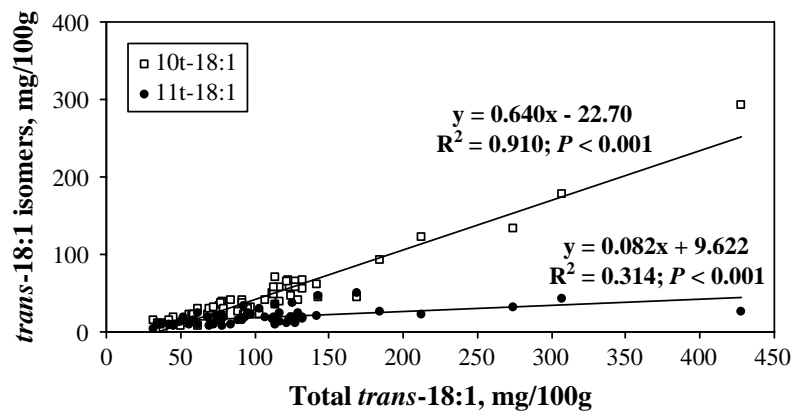

Fig. 3. Linear regressions between the total trans-18:1 and individual major trans-18:1 isomer contents (mg $100 \mathrm{~g}^{-1}$ of meat) in longissimus lumborum samples $(n=60)$. of beef (Mir et al. 2008). Together, 10t- and 11t-18:1 represented $60 \%$ of the absolute content of total trans18:1 in muscle. In addition, the absolute content of total trans-18:1 was linearly related to $10 t-18: 1\left(R^{2}=0.91\right.$, $P<0.001)$, and $11 t-18: 1\left(R^{2}=0.31, P<0.001\right.$; Fig. 3$)$, but the slope was shallower for 11t-18:1. Similar correlations were found when animals were fed a high concentrate diet ( $81 \%$ barley; Aldai et al. 2008a).

On a percentage basis, total MUFA were significantly higher in samples collected in winter compared with summer $(51.4 \%$ and $49.2 \%$, respectively; $P=0.001)$. The total MUFA were mainly influenced by the higher percentages of cis-monounsaturates $(48.9 \%$ and $46.2 \%$ in winter and summer, respectively; $P<0.001$ ), and more specifically by higher percentages of $9 c-18: 1$ $(39.6 \%$ and $37.3 \%$, respectively; $P<0.001)$ and $13 c-$ $18: 1(0.49 \%$ and $0.42 \%$, respectively; $P=0.013)$. Percentages of some cis-monounsaturates were, however, higher in summer than in winter samples $(7 c-16: 1,11 c$ 17:1, 14c-18:1, 15c-18:1; $P<0.05)$, but these were minor 
fatty acids and each represented less than $0.18 \%$ of total fatty acids. For total trans-monounsaturates, there was a tendency for a higher percentage in summer than in winter samples $(2.96$ and $2.49 \%$, respectively; $P=$ 0.051 ), which was mostly attributed to higher levels of 13t/14t-18:1, 15t-18:1 and 16t-18:1. The biochemical processes linking these trans-18:1 isomers are, however, not well understood. In general, across collection periods, higher levels of total trans-18:1 percentages were associated with higher levels of $10 t-18: 1$, and did not appear to be associated with vaccenic acid (11t-18:1) (Fig. 4). Of all the striploin steaks analyzed, the steak shown in position \#57 had a unique trans-18:1 isomer profile both in muscle (Fig. 4) and also in backfat (Fig. 1). In both these tissues from the same steak the TFA content was high, with $10 t-18: 1$ as the main isomer ( 1.03 and $1.59 \%$ for muscle and backfat, respectively) followed closely by $11 t-18: 1(0.80$ and $1.29 \%$, respectively) and $13 t / 14 t-18: 1$ (0.78 and $1.16 \%$, respectively). An explanation for the high 13t/14t-18:1 content in this particular steak is not immediately apparent.

Muscle PUFA composition and calculated ratios $(\mathrm{P} /$ $\mathrm{S}, \mathrm{n}-6 / \mathrm{n}-3)$ are presented in Table 6 . In general, there were no significant differences in the absolute content of the n-6 and n-3 PUFAs between collection periods, except $22: 6 \mathrm{n}-3$ (0.96 and $1.24 \mathrm{mg} 100 \mathrm{~g}^{-1}$ of meat in winter and summer samples, respectively; $P=0.040$ ), and in the $c / t$ dienes, except for $9 c, 15 c-18: 2$ (7.87 and $5.67 \mathrm{mg} 100 \mathrm{~g}^{-1}$ of meat in winter and summer samples, respectively; $P=0.015)$. The significant difference in DHA (22:6n-3) was opposite of what would be expected based on the assumption that winter samples might be from animals with more dietary forage in their background, since grazing on forage has been shown to enhance 18:3n-3 conversion to DHA (Wood et al. 2008). Logically, the higher level of $9 c, 15 c-18: 2$ could originate from 18:3n-3 supporting the theory that winter samples came from animals fed higher levels of forages. A pathway for $18: 3 \mathrm{n}-3$ biohydrogenation to $9 c, 15 c-18: 2$ has not yet been proposed (Destaillats et al. 2005), but

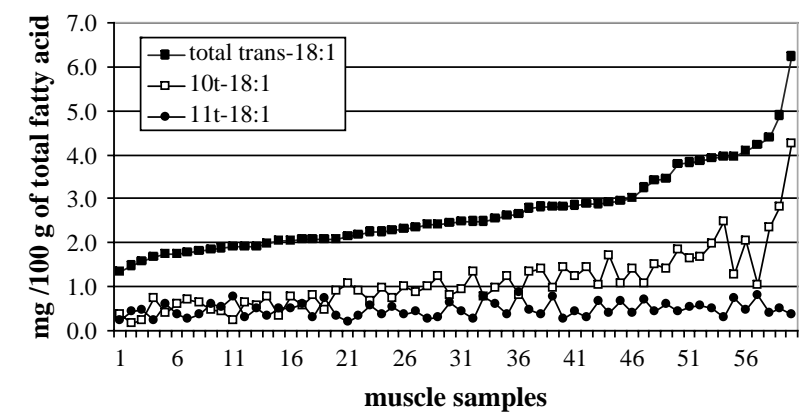

Fig. 4. Relative abundance of $10 t-18: 1$ and $11 t-18: 1$ as percent of total lipids after sorting all longissimus lumborum samples in increasing order of total trans-18:1 $(n=60)$. alternatively it could be an endogenous $\Delta^{9}$-desaturation product of 15c-18:1 (Mahfouz et al. 1980).

The P:S ratio in the lean meat was 0.11 , indicating the meat was rather high in SFA. The recommended P:S ratio for humans is $>0.4$ (Department of Health 1994; Williams 2000). Fortunately, 18:0 was the second most abundant SFA present at almost $30 \%$, and this SFA is considered less atherogenic than either $16: 0$ or 14:0 (Grundy 1994). The $n-6 / n-3$ ratio in the lean meat was 5.81 , which is only slightly more than the recommended n-6/n-3 ratio of $<5$ (Department of Health 1994; Williams 2000). This suggests that the balance of $n-6$ and n-3 PUFA in longissimus lumborum is nutritionally acceptable. Based on the recommended daily intakes of $1.6 \mathrm{~g} \mathrm{~d}^{-1}$ of total n-3 PUFA for men and $1.1 \mathrm{~g} \mathrm{~d}^{-1}$ for women (Gebauer et al. 2005), a $100 \mathrm{~g}$ serving of lean from striploin steaks would have provided $26.4 \mathrm{mg} \mathrm{n}-3$ PUFA. The absolute content of total CLA in longissimus lumborum across collection periods averaged $18.0 \pm 1.16 \mathrm{mg}$ and ranged from 3.53 to $46.6 \mathrm{mg} 100$ $\mathrm{g}^{-1}$. The major isomer was rumenic acid $(9 c, 11 t-18: 2)$ $(10.8 \pm 0.85 \mathrm{mg})$ ranging from 1.43 to $35.0 \mathrm{mg} 100 \mathrm{~g}^{-1}$ of meat, and this CLA isomer has been shown to have beneficial health effects (Ip et al. 1994; Roche et al. 2001). The next most abundant CLA isomer was $7 c, 9 t$ $18: 2(2.41 \pm 0.21 \mathrm{mg})$ ranging from 0.66 to $10.5 \mathrm{mg} 100$ $\mathrm{g}^{-1}$ of meat. The absolute average content of the major CLA isomer $(9 c, 11 t-18: 2)$ found in longissimus lumborum, albeit lower than the intake considered beneficial extrapolated from animal studies $\left(3 \mathrm{~g} \mathrm{~d}^{-1} \mathrm{Ip}\right.$ et al. 1994), was intermediate to that found in sirloin tip roasts $\left(5.0 \mathrm{mg} 100 \mathrm{~g}^{-1}\right.$ serving) and rib roasts $(40.3 \mathrm{mg}$ $100 \mathrm{~g}^{-1}$ serving) as reported by Ma et al. (1999) in Edmonton (Alberta, Canada). The two most abundant CLA isomers $(9 c, 11 t$ - and $7 t, 9 c-18: 2)$ not only represented $74 \%$ of the absolute amount of total CLA in muscle, but also showed linear relationships with the absolute amount of total CLA $\left(9 c, 11 t-18: 2, R^{2}=0.86\right.$, $P<0.001 ; 7 t, 9 c-18: 2, \quad R^{2}=0.36, \quad P<0.001$; Fig. 5). However, the slope was shallower for $7 t, 9 c-18: 2$. Several trans-18:1 and CLA isomers also appeared to be

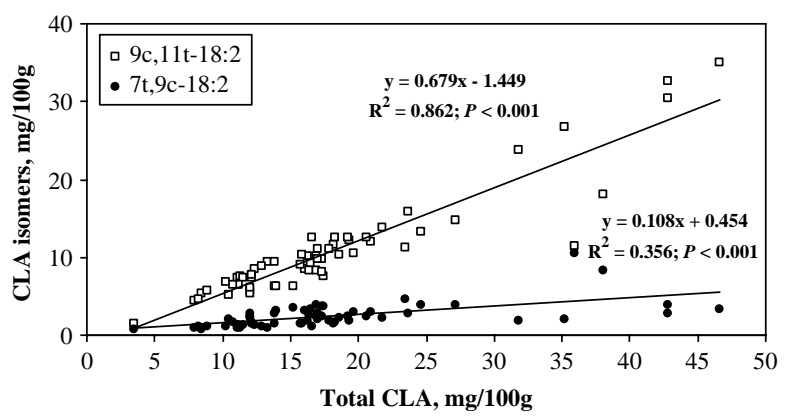

Fig. 5. Linear regressions between the total CLA and individual major CLA isomer contents $\left(\mathrm{mg} 100 \mathrm{~g}^{-1}\right.$ of meat) in longissimus lumborum samples $(n=60)$. 

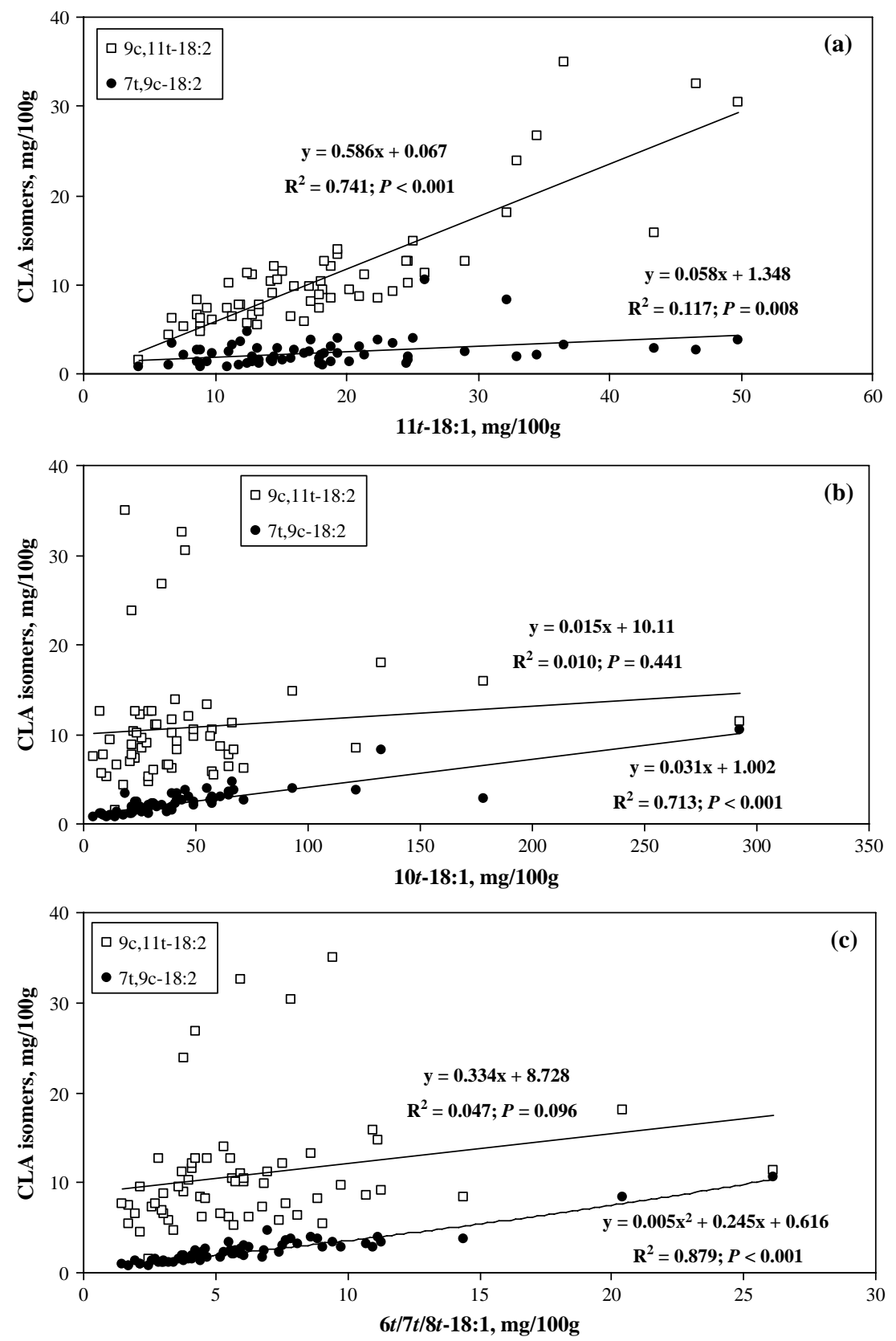

Fig. 6. Linear and quadratic regressions between the two major CLA isomers and 11t-18:1 (a), 10t-18:1 (b) and 6t/7t/8t-18:1 (c) contents (mg $100 \mathrm{~g}^{-1}$ of meat) in longissimus lumborum samples $(n=60)$.

metabolically interrelated (Fig. 6). The well known precursor-product relationship of $11 t-18: 1$ and $9 c, 11 t$ 18:2 via the $\Delta^{9}$-desaturase enzyme (Griinari et al. 2000) also showed a positive and significant relationship in this study $\left(R^{2}=0.74 ; P<0.001\right)$. The second most abundant CLA isomer $(7 t, 9 c-18: 2)$ was linearly related to $6 t / 7 t / 8 t-18: 1 \quad\left(R^{2}=0.88 ; P<0.001\right)$ supporting the previous findings of Corl et al. (2002) that $7 t-18: 1$ is converted to $7 t, 9 c-18: 2$ by $\Delta^{9}$-desaturase; its relation- ship to $10 t-18.1 \quad\left(R^{2}=0.71 ; P<0.001\right)$ was recently described (Aldai et al. 2008a).

On a percentage basis, longissimus lumborum collected in summer compared with winter had tendencies for higher levels of total PUFA (5.03 vs. $4.44 \% ; P=$ 0.085 ) and n-6 PUFA (4.25 vs. $3.75 \% ; P=0.098$; Table 4). This may be related to lower total fat in summer samples, lower neutral lipids and proportionately higher levels of PUFA rich phospholipids. Summer compared 


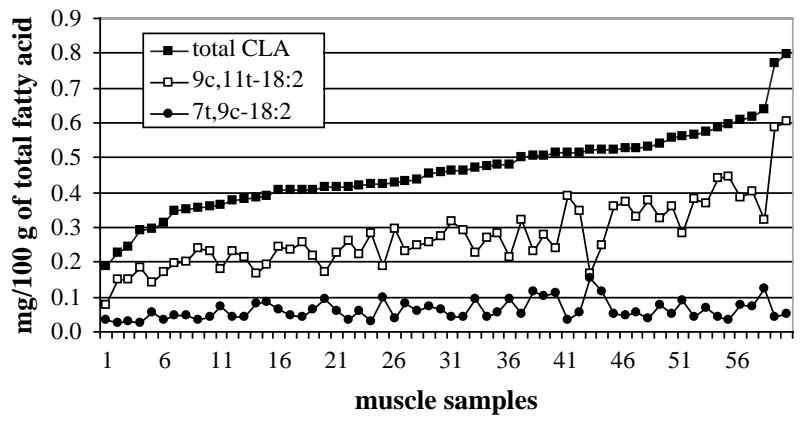

Fig. 7. Relative abundance of $9 c, 11 t-18: 2$ and $7 t, 9 c-18: 2$ as percent of total lipids after sorting all longissimus lumborum samples in increasing order of total CLA $(n=60)$.

with winter longissimus lumborum did, however, have the tendency for a greater percentage of total CLA (0.49 vs. $0.43 \% ; P=0.058)$, which was supported by higher percentages of $7 t, 9 c-18: 2$ and $10 t, 12 c-18: 2(P<0.05)$, but differences were rather low in magnitude and explanations for which are not immediately apparent. In general, across collection periods, higher levels of total CLA $(\%)$ were associated with higher levels of $9 c, 11 t-18: 2(\%)$, but not $7 t, 9 c-18: 2(\%)$ as demonstrated in Fig. 7.

\section{Nutritional Assessment of the CLA and TFA Content of Striploin Steaks}

In recent years there has been increased awareness of the potential benefits of rumenic $(9 c, 11 t-18: 2)$ and vaccenic acids $(11 t-18: 1)$ in the protection against cancer, diabetes and inflammatory diseases as demonstrated in both animal and cell models (Belury 2002; Ip et al. 2003). Some recent studies suggest that rumenic acid may even reduce the risk of certain cancers (Aro et al. 2000; Larsson et al. 2005) and acute myocardial infarction in humans (Warensjö et al. 2004). Ruminants are the major source of rumenic and vaccenic acids, but up to 20 CLA isomers (Sehat et al. 1999), and all possible trans-18:1 isomers from 4t- to 16t-18:1 (Fig. 8a) (Precht and Molkentin 1996; Fritsche et al. 2001; Cruz-Hernandez et al. 2004; Dannenberger et al. 2004) have been found in milk and meat fat of ruminants; as composition in meat and milk are quite similar. However, not all the CLA and trans-18:1isomers have beneficial effects. For example, the CLA isomers 10t,12c-18:2 (Baumgard et al. 2000) and 9t,11c-18:2 (Perfield II et al. 2007) are associated with milk fat depression, and $10 t, 12 c-18: 2$ causes several other negative effects (Larsen et al. 2003; Terpstra 2004; Tricon et al. 2004), including neutralizing the beneficial effects of rumenic acid (Tricon et al. 2004). Likewise, vaccenic acid has been shown to have the same beneficial effects as rumenic acid since it is converted to rumenic acid in animals by $\Delta^{9}$-desaturase (Griinari et al. 2000; Turpeinen et al. 2002), while the remaining trans-18:1 isomers, other than vaccenic acid (11t-18:1), have been shown to be linked to increased risk for cardiovascular disease (Mensink et al. 2003).

When Canada (Department of Health 2003) and the United States (Department of Health and Human Services, Food and Drug Administration 2003) introduced regulations requiring mandatory declaration of the TFA content on food labels, total trans was defined as the sum of all unsaturated fatty acids that contain one or more isolated double bonds, but it excluded CLA. Any foods containing less than $0.2 \mathrm{~g}$ per serving (or $2 \%$ of total fat content) in Canada, and less than $0.5 \mathrm{~g}$ per serving in the United States of America were considered free of TFA. Furthermore, this limit does not apply to food products for which the fat originates exclusively from ruminant meat or dairy products (Health Canada 2006). The exclusion of meat and dairy products from mandatory labelling of the TFA content was based on the assumption that ruminant fats consist mainly of vaccenic $(11 t-18: 1)$ and rumenic $(9 c, 11 t-18: 2)$ acids. CLA was excluded from mandatory labelling both in Canada and the United States of America because it was assumed that CLA from ruminants contains mainly $9 c, 11 t-18: 2$. Several studies have shown the potential health benefits associated with this CLA isomer (Belury 2002; Ip et al. 2003), and there were no negative reports of $9 c, 11 t-18: 2$ causing any lipoprotein changes in experimental animals (Department of Health and Human Services, Food and Drug Administration 2003).

The results of this survey show that the average total TFA content (trans-MUFA plus trans,trans-/cis,transdienes) in the longissimus lumborum was $0.128 \mathrm{~g} 100$ $\mathrm{g}^{-1}$ serving, and vaccenic acid was on average $0.018 \mathrm{~g}$ $100 \mathrm{~g}^{-1}$ serving constituting only $15 \%$ (range 5 to $29 \%$ ) of total TFA. In addition, the main trans-18:1 isomer in these steaks was not vaccenic acid, but 10t-18:1 (Fig. $8 b)$. An assessment of the CLA profiles of the striploin steaks in this study showed that about $60 \%$ of total CLA in both the longissimus lumborum and backfat was $9 c, 11 t-18: 2$, which was less than reported in other beef studies (73-78\%, Fritsche et al. 2001; 80-82\%, Nuernberg et al. 2005; 74-76\%, Kraft et al. 2008). Very similar results were recently reported in a survey conducted in the United States of America., in which the lean portion of strip steaks from beef animals fed conventional diets was compared with exclusively grassfed beef (Leheska et al. 2008). The average TFA content in the USA steaks from beef fed conventional diets was

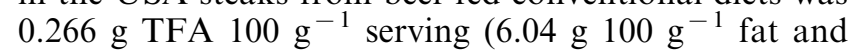
$4.4 \%$ fat content), and vaccenic acid was on average

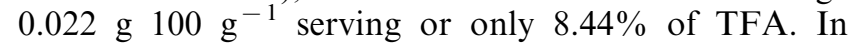
conventional USA beef, 10t-18:1 was the major trans18:1 isomer, while in grass-fed beef it was $11 t-18: 1$ (Fig. $8 \mathrm{c})$. Furthermore, the fatty acid composition of Canadian beef was recently released by the Beef Information Centre (2008) and Health Canada (2008), indicating that across Canada the TFA content for striploin steak (longissimus lumborum) was $0.14 \mathrm{~g}$ and $0.22100 \mathrm{~g}^{-1}$ serving, respectively, which were slightly higher than the 

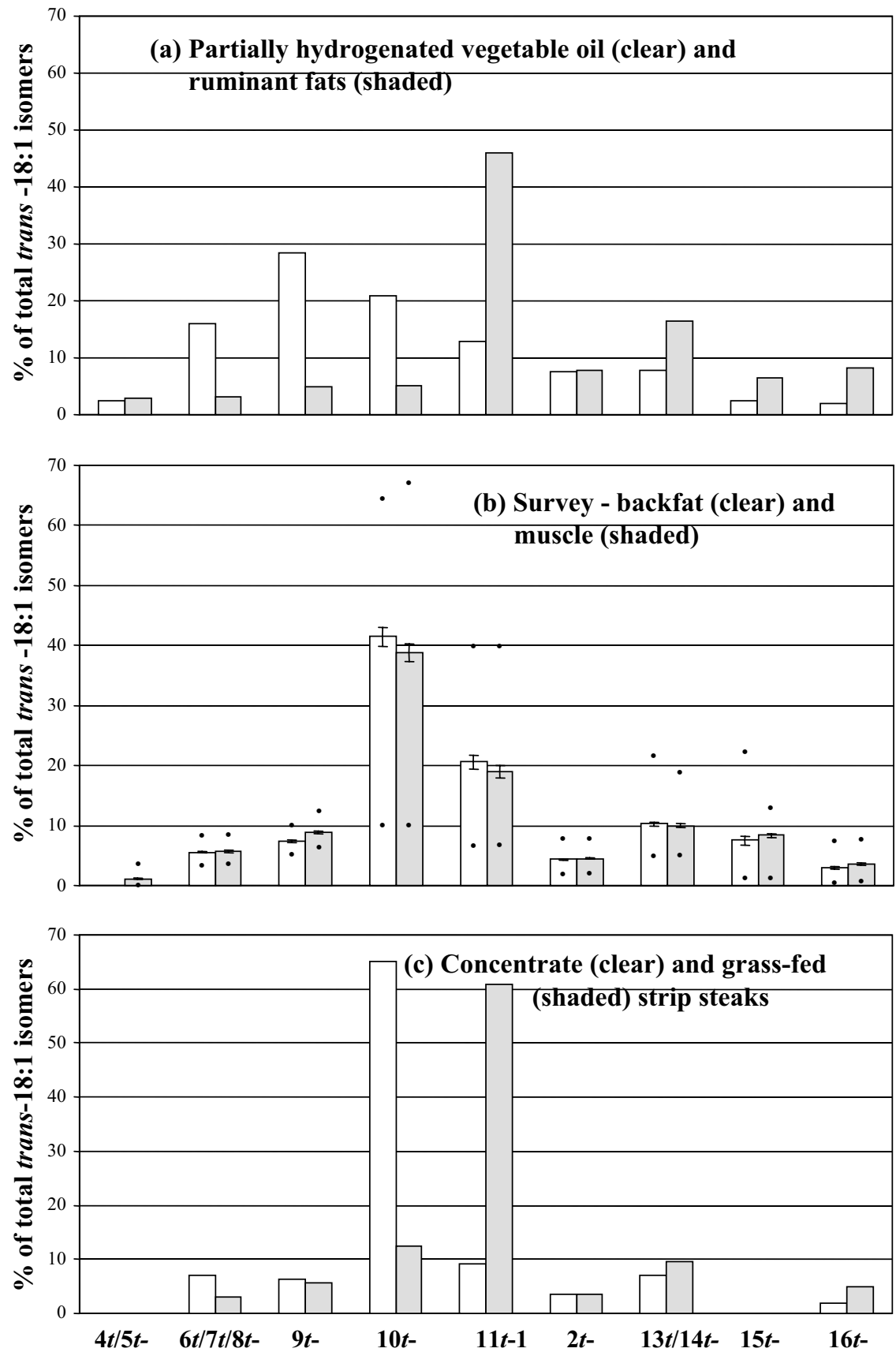

Fig. 8. Relative isomeric distribution of individual trans-18:1 isomers from (a) partially hydrogenated vegetable oils and ruminant fats (Wolff et al. 2000), (b) backfat and longissimus lumborum samples from the present study (maximum and minimum values also represented, $n=60$ ) and (c) concentrate and grass-fed beef strip steaks (Leheska et al. 2008).

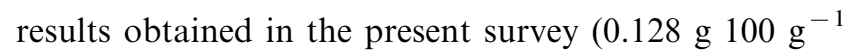
of serving). However, none of the aforementioned studies analysed individual trans isomers.

The current intensive feeding practices in beef and dairy production have led to increased levels of TFA and CLA other than vaccenic and rumenic acids in milk (Roy et al. 2006; Cruz-Hernandez et al. 2006; Eifert et al. 2006) and meat of ruminants (Hristov et al. 2006; Kraft et al. 2008; Leheska et al. 2008; current study). Therefore, the exclusion of CLA and trans-18:1 isomers from mandatory labelling of trans fatty acids may need to be reconsidered as more is understood about their positive and negative physiological effects in humans. In the present survey, however, if beef was not excluded 
because of the current regulations, only 6 of the 60 striploin steaks surveyed would have exceed the limit of

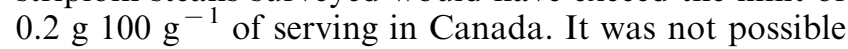
to determine how many striploin steaks from the United States of America would have exceeded the limit of $0.2 \mathrm{~g}$ per serving size, since only the means were reported by Leheska et al. (2008). On the other hand, all the Canadian striploin steaks would have been considered trans fat free in the United States of America because of the higher permissible level of TFA of $0.5{\mathrm{~g} 100 \mathrm{~g}^{-1}}^{-1}$ serving (Department of Health and Human Services, Food and Drug Administration 2003).

\section{CONCLUSIONS}

Information is widely available on the fatty acid composition of various fat and muscle tissues in beef produced under different management systems. However, to our knowledge, this is the first report of the detailed fatty acid profile of Canadian beef at the retail level. It is well known that beef fat, in general, does not meet dietary guidelines for humans regardless of animal production practices and this is mainly because of the high SFA content and the low P:S ratio. However, it is important to note that 18:0 makes up $30 \%$ of SFA in beef, which has a neutral effect on human plasma cholesterol levels. Beef can also be a source of $n-6$ and n-3 PUFA, has a good n-6/n-3 ratio and can also be a source of vaccenic and rumenic acids. Based on a $100-\mathrm{g}$ serving, the striploin steaks surveyed in the present study would not have been a good source of vaccenic and rumenic acids. Consequently, to meet general dietary guidelines for human consumption there is still room for improvement in the SFA, MUFA and PUFA composition of Canadian beef and additional targets should include reducing 10t-18:1 while increasing both rumenic and vaccenic acids.

\section{ACKNOWLEDGEMENTS}

The Education, University \& Research Department of the Basque Government (Basque Country, Spain) and the 7th European Community Program (Marie Curie International Outgoing Fellowship) are acknowledged for supporting Noelia Aldai.

Aldai, N., Dugan, M. E. R., Kramer, J. K. G., Mir, P. S. and McAllister, T. A. 2008a. Non-ionophore antibiotics do not affect the trans-18:1 and CLA composition in beef adipose tissue. J. Anim. Sci. 86: 3522-3532.

Aldai, N., Dugan, M. E. R., Martinez, A., Rolland, D. C., Kramer, J. K. G. and Osoro, K. 2008b. Effect of concentratefinishing on muscle fatty acid composition in genetically lean beef cattle. Proceedings of 54th International Congress of Meat Science and Technology, Session 2B: Human Nutrition Challenges. p. 61.

Aldai, N., Nájera, A. I., Martínez, A., Celaya, R. and Osoro, K. 2007. Correlation between carcass conformation and fat cover degree, and muscle fatty acid profile of yearling bulls depending on breed and $m h$-genotype. Livest. Sci. 107: 199-212.

Aro, A., Männistö, S., Salminen, I., Ovaskainen, M.-L., Kataja, V. and Uusitupa, M. 2000. Inverse association between dietary and serum conjugated linoleic acid and risk of breast cancer in postmenopausal women. Nutr. Cancer 38: 151-157.

Basarab, J. A., Okine, E. K., Baron, V. S., Marx, T., Ramsey, P., Ziegler, K. and Lyle, K. 2005. Methane emissions from enteric fermentation in Alberta's beef cattle population. Can. J. Anim. Sci. 85: 501-512.

Bauchart, D., Roy, A., Lorenz, S., Chardigny, J. M., Ferlay, A., Gruffat, D., Sebedio, J. L., Chilliard, Y. and Durand, D. 2007. Butters varying in trans $18: 1$ and cis-9, trans-11 conjugated linoleic acid modify plasma lipoproteins in the hypercholesterolemic rabbit. Lipids 42: 123-133.

Bauman, D. E. and Griinari, J. M. 2003. Nutritional regulation of milk fat synthesis. Ann. Rev. Nutr. 23: 203-227.

Baumgard, L. H., Corl, B. A., Dwyer, D. A., Saebo, A. and Bauman, D. E. 2000. Identification of the conjugated linoleic acid isomer that inhibits milk fat synthesis. Am. J. Physiol. Regulatory Integrative Comp. Physiol. 278: R179-R184.

Beef Information Centre. 2008. Nutrition and health. The nutrient value of Canadian Beef. [Online] Available: www.beefinfo.org. [2008 Nov. 10].

Belury, M. A. 2002. Dietary conjugated linoleic acid in health: physiological effects and mechanism of action. Annu. Rev. Nutr. 22: 505-531.

CanFax Research Services. 2008. Canada's source for cattle market information. [Online] Available: http://www.canfax.ca/ general/StatBrf.PDF [2008 Dec. 1].

Chen, M. and Wolin, M. J. 1979. Effect of monensin and lasalocid-sodium on the growth of methanogenic and rumen saccharolytic bacteria. Appl. Environ. Microbiol. 72: 72-77.

Corl, B. A., Baumgard, L. H., Griinari, J. M., Delmonte, P., Morehouse, K. M., Yurawecz, M. P. and Bauman, D. E. 2002. Trans-7, cis-9 CLA is synthesized endogenously by $\Delta^{9}$ desaturase in dairy cows. Lipids 37: 681-688.

Cruz-Hernandez, C., Deng, Z., Zhou, J., Hill, A. R., Yurawecz, M. P., Delmonte, P., Mossoba, M. M., Dugan, M. E. R. and Kramer, J. K. G. 2004. Methods to analyze conjugated linoleic acids (CLA) and trans-18:1 isomers in dairy fats using a combination of GC, silver ion TLC-GC, and silver ion HPLC. J. AOAC Int. 87: 545-560.

Cruz-Hernandez, C., Kramer, J. K. G., Kennelly, J. J., Glimm, D. R., Sorensen, B. M., Okine, E., Goonewardene, L. A. and Weselake, R. J. 2007. Evaluating the conjugated linoleic acid and trans 18:1 isomers in milk fat of dairy cows fed increasing amounts of sunflower oil and a constant level of fish oil. $\mathbf{J}$. Dairy Sci. 90: 3786-3801.

Cruz-Hernandez, C., Kramer, J. K. G., Kraft, J., Santercole, V., Or-Rashid, M., Deng, Z., Dugan, M. E. R., Delmonte, P. and Yurawecz, M. P. 2006. Systematic analysis of trans and conjugated linoleic acids in the milk and meat of ruminants. Pages 45-93 in M. P. Yurawecz, J. K. G. Kramer, O. Gudmundsen, M. W. Pariza, and S. Banni, eds. Advances in conjugated linoleic acid research, Vol 3. AOCS Press, Champaign, IL.

Dannenberger, D., Lorenz, S., Nuernberg, G., Scollan, N. D., Ender, K. and Nuernberg, K. 2006. Analysis of fatty aldehyde composition, including 12-methyltridecanal, in plasmalogens from longissimus muscle of concentrate- and pasture-fed bulls. J. Agric. Food Chem. 54: 182-188. 
Dannenberger, D., Nuernberg, G., Scollan, N., Schabbel, W., Steinhart, H., Ender, K. and Nuernberg, K. 2004. Effect of diet on the deposition of $n-3$ fatty acids, conjugated linoleic and C18:1trans fatty acid isomers in muscle lipids of German Holstein bulls. J. Agric. Food Chem. 52: 6607-6615.

Department of Health and Human Services, Food and Drug Administration. 2003. Food labeling; trans fatty acids in nutrition labeling; nutrient content claims, and health claims; Final rule, July 11, 2003. Federal Register 68 (No. 133): 41434 41506.

Department of Health. 1994. Report on health and social subjects. No. 46. Nutritional aspects of cardiovascular disease. Her Majesty's Stationery Office, London, UK.

Department of Health. 2003. Regulations amending the food and drug regulations (Nutritional labeling, nutrient content claims and health claims), Canada Gazette, Part II (Ottawa, Canada) 137, No 1, 209.

Destaillats, F., Trottier, J. P., Galvez, J. M. G. and Angers, P. 2005. Analysis of a-linolenic acid biohydrogenation intermediates in milk fat with emphasis on conjugated linolenic acids. J. Dairy Sci. 88: 3231-3239.

Dugan, M. E. R., Kramer, J. K. G., Robertson, W. M., Meadus, W. J., Aldai, N. and Rolland, D. C. 2007. Comparing subcutaneous adipose tissue in beef and muskox with emphasis on trans 18:1 and conjugated linoleic acids. Lipids 42: 509-518. Dugan, M. E. R., Rolland, D. C., Aalhus, J. L., Aldai, N. and Kramer, J. K. G. 2008. Subcutaneous fat composition of youthful and mature Canadian beef: emphasis on individual conjugated linoleic acid and trans-18:1 isomers. Can. J. Anim. Sci. 88: 591-599.

Duncan, W. R. H. and Garton, G. A. 1967. The fatty acid composition and intramolecular structure of triglycerides derived from different sites in the body of the sheep. J. Sci. Food Agric. 18: 99-102.

Eifert, E. C., Lana, R. P. Lanna, D. P. D., Leopoldino, W. M., Arcuri, P. B., Leão, M. I., Cota, M. and Valadares Filho. S. C. 2006. Milk fatty acid profile of cows fed monensin and soybean oil in early lactation. Rev. Bras. Zootecn. 35: 219-228. Fritsche, J., Fritsche, S., Solomon, M. B., Mossoba, M. M., Yurawecz, M. P., Morehouse, K. and Ku, Y. 2000. Quantitative determination of conjugated linoleic acid isomers in beef fat. Eur. J. Lipid Sci. Technol. 102: 667-672.

Gebauer, S., Harris, W. S., Kris-Etherton, P. M. and Etherton, T. D. 2005. Dietary $n-6: n-3$ fatty acid ratio and health. Pages 221-248 in C. C. Akoh and O-M. Lai, eds. Healthful lipids. AOCS, Champaign, IL.

Griinari, J. M., Corl, B. A., Lacy, S. H., Chouinard, P. Y., Nurmela, K. V. V. and Bauman, D. E. 2000. Conjugated linoleic acid is synthesized endogenously in lactating dairy cows by $\Delta^{9}$-desaturase. J. Nutr. 130: 2285-2291.

Grundy, S. M. 1994. Lipids and cardiovascular disease. Pages 211-279 in D. Kritchevsky and K. K. Carroll, eds. Nutrition and disease update. Heart disease. AOCS Press, Champaign, IL.

Gustafson, R. H. and Bowen, R. E. 1997. Antibiotic use in animal agriculture. A review. J. Appl. Microbiol. 83: 531-541. Health Canada. 2006. Food and nutrition. TRANSforming the food supply. Report of the Trans Fat Task Force Submitted to the Minister of Health. [Online] Available: http://www.hcsc.gc.ca/fn-an/alt_formats/hpfb-dgpsa/pdf/nutrition/tf-gt_reprap-eng.pdf [2008 Oct. 29].
Health Canada. 2008. Food and nutrition. Nutrient data. The Canadian Nutrient File (Food Code: 6107). [Online] Available: http://webprod.hc-sc.gc.ca/cnf-fce/serving-portion.do?lang = eng\&id =6107 [2008 March 31].

Hodgson, J. M., Wahlquist, M. L., Boxall, J. A. and Balazs, N. D. 1996. Platelet trans fatty acids in relation to angiographically assessed coronary artery disease. Artherosclerosis 120: $147-154$.

Horrocks, L. A. 1972. Content, composition, and metabolism of mammalian and avian lipids that contain ether groups. Pages 177-272 in F. Snyder, ed. Ether lipids. Chemistry and biology. Academic Press, New York, NY.

Hristov, A. N., Kennington, L. R., McGuire, M. A. and Hunt, C. W. 2005. Effects of diets containing linoleic acid- or oleic acid-rich oils on ruminal fermentation and nutrient digestibility, and performance and fatty acid composition of adipose tissue and muscle tissues of finishing cattle. J. Anim. Sci. 83: 1312-1321.

Ip, C., Singh, M., Thompson, H. J. and Scimeca, J. A. 1994. Conjugated linoleic acid suppresses mammary carcinogenesis and proliferative activity of the mammary gland in the rat. Cancer Res. 54: 1212-1215.

Ip, M. M., Masso-Welch, P. A. and Ip, C. 2003. Prevention of mammary cancer with conjugated linoleic acid: role of the stroma and the epithelium. J. Mammary Gland Biol. 8: 103118.

Kennedy, P. M., Young, B. A. and Christopherson, R. J. 1977. Studies on the relationship between thyroid function, cold acclimation and retention time of digesta in sheep. J. Anim. Sci. 45: 1084-1090.

Kepler, C. R., Hirons, K. P., McNeil, J. J. and Tove, S. B. 1966. Intermediates and products of the biohydrogenation of linoleic acid by Butyrivibrio fibrisolvens. J. Biol. Chem. 241: 1350-1354. Kouba, M., Hermia, D. and Le Dividich, J. 1999. Influence of a high ambient temperature on stearoyl-CoA-desaturase activity in the growing pig. Comp. Biochem. Phys. B. 124: 7-13.

Kraft, J., Kramer, J. K. G., Schoene, F., Chambers, J. R. and Jahreis, G. 2008. Extensive analysis of long-chain polyunsaturated fatty acids, CLA, trans-18:1 isomers, and plasmalogenic lipids in different retail beef types. J. Agric. Food Chem. 56: $4775-4782$.

Kramer, J. K. G., Fellner, V., Dugan, M. E. R., Sauer, F. D., Mossoba, M. M. and Yurawecz, M. P. 1997. Evaluating acid and base catalysts in the methylation of milk and rumen fatty acids with special emphasis on conjugated dienes and total trans fatty acids. Lipids 32: 1219-1228.

Kramer, J. K. G., Hernandez, M., Cruz-Hernandez, C., Kraft, J. and Dugan, M. E. R. 2008. Combining results of two GC separations partly achieves determination of all cis and trans $16: 1,18: 1,18: 2,18: 3$ and CLA isomers of milk fat as demonstrated using Ag-ion SPE fractionation. Lipids 43: 259-273.

Kramer, J. K. G., Sehat, N., Dugan, M. E. R., Mossoba, M. M., Yurawecz, M. P., Roach, J. A. G., Eulitz, K., Aalhus, J. L., Schaefer, A. L. and Ku, Y. 1998. Distribution of conjugated linoleic acid (CLA) isomers in tissue lipid classes of pigs fed a commercial CLA mixture determined by GC and silver ionHPLC. Lipids 33: 549-558.

Larsen, T. M., Toubro, S. and Astrup, A. 2003. Efficacy and safety of dietary supplements containing CLA for the treatment of obesity: Evidence from animal and human studies. J. Lipid Res. 44: 2234-2241. 
Larsson, S. C., Bergkvist, L. and Wolk, A. 2005. High-fat dairy food and conjugated linoleic acid intakes in relation to colorectal cancer incidence in the Swedish mammography cohort. Am. J. Clin. Nutr. 82: 894-900.

Leheska, J. M., Thompson, L. D., Howe, J. C., Hentges, E., Boyce, J., Brooks, J. C., Shriver, B., Hoover, L. and Miller, M. F. 2008. Effects of conventional and grass feeding systems on the nutrient composition of beef. J. Anim. Sci. 88: 35753585 .

Ma, D. W. L., Wierzbicki, A. A., Field, C. J. and Clandinin, M. T. 1999. Conjugated linoleic acid in Canadian dairy and beef products. J. Agric. Food Chem. 47: 1956-1960.

Mahfouz, M. M., Valicenti, A. J. and Holman, R. T. 1980. Desaturation of isomeric trans-octadecenoic acids by rat liver microsomes. Biochim. Biophys. Acta 618: 1-12.

Mensink, R. P., Zock, P. L., Kester, A. D. M. and Katan, M. B. 2003. Effects of dietary fatty acids and carbohydrates on the ratio of serum total to HDL cholesterol and on serum lipids and apolipoproteins: A meta-analysis of 60 controlled trials. Am. J. Clin. Nutr. 77: 1146-1155.

Mir, P. S., Dugan, M. E. R., Hem M. L, Entz, T. and Yip, B. 2008. Effects of dietary sunflower seeds and tylosin phosphate on production parameters, carcass characteristics, fatty acid composition, and liver abscess incidence in crossbred steers. J. Anim. Sci. 86: 3125-3136.

Nuernberg, K., Nuernberg, G., Ender, K., Dannenberger, D., Schabbel, W., Grumbach, S., Zupp, W. and Steinhart, H. 2005. Effect of grass $v s$ concentrate feeding on the fatty acid profile of different fat depots in lambs. Eur. J. Lipid Sci. Technol. 107: 737-745.

Perfield II, J. W., Lock, A. L., Griinari, J. M. Sæbø, A., Delmonte, P., Dwyer, D. and Bauman, D. E. 2007. Trans-9, cis11 conjugated linoleic acid reduces milk fat synthesis in lactating dairy cows. J. Dairy Sci. 90: 2211-2218.

Precht, D. and Molkentin, J. 1996. Rapid analysis of the isomers of trans-octadecenoic acid in milk fat. Int. Dairy J. 6: 791-809.

Purchas, R. W., Knight, T. W. and Busboom, J. R. 2005. The effect of production system and age on concentrations of fatty acids in intramuscular fat of longissimus and triceps brachii muscles of Angus-cross heifers. Meat Sci. 70: 597-603.

Ratnayake, W. M. N. and Zehaluk, C. 2005. Trans fatty acids in foods and their labeling regulations. Pages 1-32 in C. C. Akoh and O.-M. Lai, eds. Healthful lipids, AOCS Press, Champaign, IL.

Realini, C. E., Duckett, S. K., Brito, G. W., Dalla Rizza, M. and De Mattos, D. 2004. Effect of pasture vs concentrate feeding with or without antioxidants on carcass characteristics, fatty acid composition, and quality of Uruguayan beef. Meat Sci. 66: $567-577$.

Roche, H. M., Noone, E. Nugent, A. and Gibney, M. J. 2001. Conjugated linoleic acid: a novel therapeutic nutrient. Nutr. Res. Rev. 14: 173-187.

Roy, A., Chardigny, J. M., Bauchart, D., Ferlay, A., Lorenz, S., Durand, D., Gruffat, D., Faulconnier, Y., Sebedio, J. L. and Chilliard, Y. 2007. Butter rich in trans10-C18:1 plus cis9,trans11-CLA differentially affects plasma lipids and aortic streak in experimental atherosclerosis in rabbits. Animal 1: $467-476$.
Roy, A., Ferlay, A., Shingfield, K. J. and Chilliard, Y. 2006. Examination of the persistency of milk fatty acid composition responses to plant oils in cows given different basal diets, with particular emphasis on trans-C18:1 fatty acids and isomers of conjugated linoleic acid. Anim. Sci. 82: 479-492.

Rule, D. C., Smith, S. B. and Romans, J. R. 1995. Fatty acid composition of muscle and adipose tissue of meat animals. Pages 144-165 in S. B. Smith and D. R. Smith, eds. The biology of fat in meat animals. Current advances. American Society of Animal Science, Champaign, IL.

Russell, J. B. and Strobel, H. J. 1989. Effect of ionophores on ruminal fermentation. Appl. Environ. Microbiol. 55: 1-6.

Santercole, V., Mazzette, R., De Santis, E. P. L., Banni, S., Goonewardene, L. and Kramer, J. K. G. 2007. Total lipids of Sarda sheep meat that include the fatty acid and alkenyl composition and the CLA and trans-18:1 isomers. Lipids 42: 361-382.

SAS Institute, Inc. 2001. SAS user's guide: Statistics. SAS for Windows, Release 8.2. SAS Institute, Inc., Cary, NC.

Scollan, N., Hocquette, J.-F., Nuernberg, K., Dannenberger, D., Richardson, I. and Moloney, A. 2006. Innovations in beef production systems that enhance the nutritional and health value of beef lipids and their relationship with meat quality. Meat Sci. 74: 17-33.

Sehat, N., Rickert, R., Mossoba, M. M., Kramer, J. K. G., Yurawecz, M. P., Roach, J. A. G., Adlof, R. O., Morehouse, K. M., Fritsche, J., Eulitz, K. D., Steinhart, H. and Ku, Y. 1999. Improved separation of conjugated fatty acid methyl esters by silver ion-high-performance liquid chromatography. Lipids 34: 407-413.

Siebert, B. D., Pitchford, W. S., Kruk, Z. A., Kuchel, H., Deland, M. P. B. and Bottema, C. D. K. 2003. Differences in ? desaturase activity between Jersey- and Limousin-sired cattle. Lipids 38: 539-543.

Snyder, F., Lee, T. and Wykle, R. L. 1985. Ether-linked glycerolipids and their bioactive species: enzymes and metabolic regulation. Pages $1-58$ in A. N. Martonosi, ed. The enzymes of biological membranes. Vol. 2. Plenum Press, New York, NY.

Terpstra, A. H. M. 2004. Effect of conjugated linoleic acid on body composition and plasma lipids in humans: An overview of the literature. Am. J. Clin. Nutr. 79: 352-361.

Tricon, S., Burdge, G. C., Kew, S., Banerjee, T., Russell, J. J., Jones, E. L., Grimble, R. F., Williams, C. M., Yaqoob, P. and Calder, P. C. 2004. Opposing effects of cis-9, trans-11 and trans-10,cis-12 conjugated linoleic acid on blood lipids in healthy humans. Am. J. Clin. Nutr. 80: 614-620.

Tume, R. K. 2004. The effects of environmental factors on fatty acid composition and the assessment of marbling in beef cattle: a review. Aust. J. Exp. Agric. 44: 663-668.

Turpeinen, A. M., Mutanen, M., Aro, A., Salminen, I., Basu, S., Palmquist, D. L. and Griinari, J. M. 2002. Bioconversion of vaccenic acid to conjugated linoleic adid in humans. Am. J. Clin. Nutr. 76: 504-510.

Warensjö, E., Jansson, J.-H., Berglund, L., Boman, K., Ahréns, B., Weinehall, L., Lindahl, B., Hallsmans, G. and Vessby, B. 2004. Estimated intake of milk fat is negatively associated with cardiovascular risk factors and does not increase the risk of a first acute myocardial infarction. A prospective case - control study. Br. J. Nutr. 91: 635-642. 
Williams, C. M. 2000. Dietary fatty acids and human health. Ann. Zootech. 49: 165-180.

Wolff, R. L., Combe, N. A., Destaillats, F., Boue, C., Precht, D., Molketin, J. and Entressangles, B. 2000. Follow-up of the $\Delta 4$ to $\Delta 16$ trans-18:1 isomer profile and content in French processed foods containing partially hydrogenated vegetable oils during the period 1995-1999. Analytical and nutritional implications. Lipids 35: 815-825.
Wood, J. D., Enser, M., Fisher, A. V., Nute, G. R., Sheard, P. R., Richardson, R. I., Hughes, S. I. and Whittington, F. M. 2008. Fat deposition, fatty acid composition and meat quality: A review. Meat Sci. 78: 343-358.

World Health Organization. 2003. Diet, nutrition and the prevention of chronic diseases. Report of a joint WHO/FAO expert consultation. WHO technical report series 916, Geneva, Switzerland. 